\title{
MINORITY DISCOUNTS AND CONTROL PREMIUMS IN APPRAISAL PROCEEDINGS
}

\author{
By Richard A. Booth
}

In a merger, a stockholder usually has a statutory right of dissent and appraisal (appraisal for short). That is, a stockholder who objects to the terms of a merger may demand to be paid in cash the fair value of his or her shares exclusive of any gain or loss that may arise from the merger itself. ${ }^{1}$ Most courts and commentators agree that it is inappropriate to apply a minority discount in the context of an appraisal proceeding even though the market value of minority shares may be somewhat depressed for a variety of reasons. ${ }^{2}$ Indeed, the purpose of appraisal is to double check whether the price paid in a merger is a fair one. Thus, the appraisal remedy is founded on the possibility that market prices (broadly defined) may be wrong.

As the Delaware Supreme Court has stated, the goal of an appraisal proceeding should be to determine the value of the corporation as a whole, not the value of particular shares, and to award the found value per share to all dissenting stockholders. ${ }^{3}$ Minority stockholders are still stockholders. The shares they own are legally equal to each and every other share of the same class. The fact that they cannot exercise control is no reason to assign minority shares a lesser value than other shares. Thus, a dissenting shareholder should ordinarily receive a pro rata share of the value of the corporation without any discount simply because the minority lacks control.

But does this mean that a minority shareholder is also entitled to a share of the control value of the corporation? That is, should an appraisal court determine the price at which a controlling shareholder could sell control and then award a pro rata share of that amount to dissenting stockholders? Surprisingly, several courts that have addressed the question have so ruled. ${ }^{4}$ In addition, some courts have ruled that reliance on market prices of comparable

\footnotetext{
${ }^{1}$ The extent of the right varies from state to state. In Delaware, appraisal is available only in connection with mergers. See Delaware General Corporation Law (DGCL) $\S \S 253,262,263$. In other jurisdictions, appraisal is available in connection with all sorts of fundamental transactions (including sales of assets, share exchanges, and sometimes even amendments to the articles of incorporation). See, e.g., Model Business Corporation Act (MBCA) $\S 13.01$ to 13.31 and Official Comments thereto.

${ }^{2}$ The leading Delaware case is Cavalier Oil Corp. v. Harnett, 564 A.2d 1137 (Del. 1989), which involved appraisal proceedings following a short form merger. For a listing of other cases by jurisdiction and commentary addressing the issue of discounts, see the appendix.

${ }^{3}$ Cavalier Oil Corp. v. Harnett, 564 A.2d 1137 (Del. 1989). Accord Paskill Corp. v. Alcoma Corp., 747 A.2d 549 (Del. 2000).

${ }^{4}$ See M.G. Bancorporation, Inc. v. LeBeau, 737 A.2d 513 (Del. 1999); Nebel v. Southwest Bancorp, Inc., 1995 Del. Ch. LEXIS 80 (related case based on breach of fiduciary duty); Rapid-American Corp. v. Harris, 603 A.2d 796 (Del. 1992); Borruso v. Communications Telesystems International, 753 A.2d 451 (Del.Ch. 1999) (adding 30 percent control premium because comparable company analysis reflects inherent minority discount); Hintmann v. Fred Weber, Inc., 1998 Del. Ch. LEXIS 26 (Del.Ch. 1998) (20 percent premium added to value of subsidiary shares). See also Kleinwort Benson Ltd. v. Silgan Corp., 1995 Del. Ch. LEXIS 75 (affirming addition of premium to market price to adjust for inherent minority discount but disallowing portion attributable to merger gain). But see Cooper v. Pabst Brewing Corp., 1993 Del. Ch. LEXIS 91; Salomon Brothers, Inc. v. Interstate Bakers Corp., 1992 Del. Ch.
} 
companies and even the capital asset pricing model (CAPM) to determine capitalization rate results in a built-in or inherent minority discount thus requiring that a premium for control be added. $^{5}$

It is the thesis here that the routine addition of control premium is inconsistent with settled corporation law and good policy that there is no basis for the assumption that market prices routinely build in a minority discount. In other words, the courts have gone too far in an effort to guard against minority discounts and have infringed on the legitimate rights of majority shareholders to enjoy the recognized perquisites of control.

\section{Premiums and Discounts - Know the Difference}

It is often said that fairness is a range of values. ${ }^{6}$ And so it is in more ways than one. First, valuation is inherently imprecise. But second, and more important for present purposes, there are several standards of valuation. In some cases one may want to estimate the price at which one could buy or sell a controlling interest in a company. ${ }^{7}$ In other cases, one may want to estimate fair market value, that is, the value at which shares would trade in a completely undistorted market. Finally, in still other cases, one may seek to estimate the price at which an investor could actually sell shares.

Control shares ordinarily -- perhaps always -- carry a premium over fair market value, because (at the very least) a controlling shareholder can dictate business policies within a broad

LEXIS 100 (both rejecting addition of premium as incorporating post merger value). Cf. Cede \& Co. v. Technicolor, Inc., 684 A.2d 289 (Del. 1996) (appraisal price in second step freeze out merger should have included gain from changes in business practice after bidder assumed control through tender offer). For cases from other jurisdictions, see the appendix. In most of the Delaware cases in which a control premium has been added, it has been added to the value of subsidiary shares. Arguably, there is a stronger case for adding a premium to subsidiary shares in the context of appraisal of parent company shares in that subsidiary is an asset of the parent and is owned (and controlled) for the benefit of all parent stockholders. Where the subsidiary is the primary asset of the parent, however, there is something more than a little artificial about bootstrapping a subsidiary premium into the valuation of the parent. (For a similar observation, see Miller v. Agranoff, 2001 Del.Ch.LEXIS 71, at *51, note 45.) Moreover, one must be careful to allocate a control premium over all of the shares. In some cases, a controlling block may be salable at a higher premium than all of the shares. For example, it is at least conceivable that a buyer might be willing to pay a 100 premium for 51 percent of the shares, but only a 50 percent premium for 100 percent of the shares. On the other hand, one could also argue in such cases that the control premium is at the expense of the minority and may even signal the likelihood of looting by the buyer. See McMullin v. Beran, 2000 Del. LEXIS 481.

5 See M.G. Bancorporation, Inc. v. LeBeau, 737 A.2d 513 (Del. 1999); Borruso v. Communications Telesystems International, 753 A.2d 451 (Del.Ch. 1999) (adding 30 percent control premium because comparable company analysis reflects inherent minority discount). But see Cede \& Co. v. Technicolor, Inc., 1990 Del. Ch. LEXIS 259 (ruling that use of CAPM is not the same as reliance on market price).

${ }^{6}$ See, e.g., MBCA $\$ 8.61$, Official Comment 3.

${ }^{7}$ Indeed even here the answer may depend on whether one is buying or selling and the percentage of the shares that one is buying or selling. After all, one may buy control by buying all of the shares or by buying some lesser percentage often even substantially less than a majority. 
legal range. ${ }^{8}$ Moreover, a buyer of controlling shares may be willing to pay a premium because the buyer plans to change business policies in such a way as to increase profits. ${ }^{9}$ Or the buyer may plan to combine the acquired business with one or more other businesses in such a way as to increase the value of the whole, creating synergistic gains. ${ }^{10}$

Sometimes actual market price is less than fair market price, because (1) there may be no ready market for the shares (a marketability discount) or (2) there may be a danger that the controlling shareholder will use control in such a way as to extract more than rightful value from the corporation (a true minority discount). ${ }^{11}$ But there is no reason to think that these factors will

\footnotetext{
${ }^{8}$ This is true in situations in which control shares are sold, but it is not necessarily the case in all circumstances. If it were, presumably controlling shareholders would sell their companies en mass until they came to rest in the hands of the highest valuing buyers and the process would grind to a halt or at least some sort of equilibrium. Indeed, it is arguable that sales of control typically arise in exceptional circumstances in which sellers recognize that control can in fact be sold at a premium and that in most situations the transaction costs of selling control are sufficient to obviate any clear gain over fair market value.
}

${ }^{9}$ Even though the buyer of control will ordinarily try to conceal plans for change that might lead to increased value, the seller knows at the very least that the buyer must think that the subject company is worth more than the price to be paid. Indeed, studies indicate that buyers of control generally pay a premium that is roughly equal to all of the gain in excess of an ordinary return (measured per share). Thus, sellers of control apparently insist on (and get) some share of the gain even if they do not know what it is. As I have argued elsewhere, even scattered and diversified public shareholders who are otherwise price-takers, may act as if they are party to a one-on-one negotiation in connection with a change of control or cashout transaction. See Richard A. Booth, The Efficient Market, Portfolio Theory and the Downward Sloping Demand Hypothesis, 68 N.Y.U. L. Rev. 1187, 1202-1203 (1993). Moreover, it is unclear how scattered shareholders really are given that about half of all shares are held by institutions and given that the law allows individual shareholders to piggyback on the strategies of bigger shareholders in various ways.) As discussed further below, downward sloping demand may offer an alternative explanation for premiums. If so, one would think that the larger the percentage of shares sought the larger the premium. One might call this a technical premium as opposed to a fundamental premium. If technical factors are the predominant source of premiums one would expect premiums to be paid irrespective of the gains anticipated from the transaction. Studies bear out this phenomenon to some extent. See Miller v. Agranoff, 2001 Del.Ch.LEXIS 71, at *55, note 50. But it is somewhat unclear under this model whether a large holdout minority in (say) a two step transaction would insist on a still higher premium or would settle for whatever premium was accepted by the minority. And it is even less clear whether a standing minority would insist on as big a premium as would a holdout minority. (In both cases, state takeover law and Delaware appraisal law presumably incline minority shareholders to demand somewhat bigger premiums than they otherwise would demand.) It also seems likely that because voting entails less risk for shareholders than tendering, one would expect smaller premiums in consensual deals (although shareholders may also be inclined to trust a board of directors recommendation). Studies also bear out this phenomenon. See John C. Coates IV, Measuring the Domain of Mediating Hierarchy: How Contestable Are U.S. Public Corprations?, 24 J. Corp. L. 837 (1999). In any event, if technical factors are the primary source of premiums, then premiums may be expected to differ according to how many shares are sought and how and when they are sought. This suggests that the reluctance of the Delaware courts to consider the circumstances of a transaction and to insist instead on a uniform and idealized standard of value in appraisal is out of line with investor expectations.

${ }^{10}$ The idea of synergy has been discussed at length. See Victor Brudney \& Marvin Chirelstein, Fair Shares in Corporate Mergers and Takeovers, 88 Harv. L. Rev. 297 (1974); John C. Coates, IV, “Fair Value” As an Avoidable Rule of Corporate Law: Minority Discounts in Conflict Transactions, 147 U. Pa. L.Rev. 1251 (1999). See also PCG $\$ 7.22$, Reporter's Note 6. It is unclear that it is in fact a source of control premiums. See Miller v. Agranoff, 2001 Del.Ch.LEXIS 71, at $* 55$, note 50 (collecting studies).

\footnotetext{
${ }^{11}$ The notion of rightful value is itself a bit fuzzy in that a controlling shareholder is clearly entitled to be paid a salary for his or her services and may also arrange for a variety of incentives such as stock options. No one would argue that the non controlling shareholders are entitled to their share of these. Thus, control value is not necessarily
} 
always obtain. Accordingly, it is not necessarily the case that actual market price is always less than fair market price. If it were, then there would be no such thing as a fair market price. ${ }^{12}$ Nevertheless, the distinction between fair value and fair market value has become quite important particularly in Delaware.

The courts generally recognize that a controlling shareholder may sell to a third party (and thereby sell control of the corporation) at a premium over the market price. A controlling shareholder is under no general obligation to share that premium with other shareholders. ${ }^{13}$ Indeed, the courts also recognize that a relatively large shareholder may be able to command a premium over market price and that a corporation repurchasing such shares may properly pay a higher price to that shareholder. ${ }^{14}$ Thus, it is clear that corporation law does not guarantee to minority shareholders the right to a share of a control premium.

\section{Minority Discounts and Marketability Discounts}

Although many courts and commentators use the terms minority discount and marketability discount more or less interchangeably, the two are really quite distinct from each other. The idea of a minority discount does not properly refer to the fact that minority shares ordinarily will trade at a price that is less than the price that a controlling shareholder might command in a sale of control. Rather, the term minority discount as properly understood refers to a discount from the price that would be set for non-control shares in an active market simply because they are minority shares and have no power to influence the governance of the corporation and may therefore be exposed to the possibility of looting.

A minority discount should be distinguished from a marketability discount. In an active market, small blocks of shares are ordinarily quite easy to trade and a single trade ordinarily has little effect on the market price. If, however, there are relatively few shares outstanding or there are relatively few shareholders, it may be difficult to trade those shares and a buyer may only be willing to pay a price that reflects the difficulty he or she would have in later reselling the shares. Thus, a marketability discount refers to a discount from what a fair trading price would be if

limited to the intangible value of being able to dictate business policy. It may also include the effective right to a job and a lucrative compensation package, perhaps one that even rises to the level of a significant percentage of the income of the company.

${ }^{12}$ Ironically, the appraisal statutes of most states contain a market exception for companies that are listed on an exchange or that have 2000 or more shareholders which rather settles the question (in the negative) of whether market price should be viewed as including an inherent discount in those states. The Delaware statute also contains a market exception but only for stock for stock mergers. From 1984 to 1999, the MBCA contained no market exception. A market exception was added in 1999, including an exception to the exception for conflicting interest transactions in which a 20 percent or more stockholder has an interest in the surviving corporation, a provision that is clearly designed to deal with (true) minority discounts.

${ }^{13}$ See ALI Principles of Corporate Governance (PCG) §5.16 (1994); Thorpe v. CERBCO, Inc., 676 A.2d 436 (Del. 1996). But see Perlman v. Feldmann, 219 F.2d 173 (2d Cir. 1955) (requiring controlling shareholder to share control premium prorata with minority). For a discussion of the remedy in Perlman and the possible source of the control premium therein, see HAMILTON \& BOOTH, CORPORATION FINANCE 734-36 (West 2001).

${ }^{14}$ See Grobow v. Perot, 539 A.2d 180 (Del. 1988). 
there were an active market for the shares. Large blocks of shares (even those that have some power to affect corporate policies) may also suffer from a marketability discount, because it is often difficult to trade a large block of shares without affecting the market price. Thus, it is not at all unusual for a large number of shares to trade at a block discount.

Most courts and commentators seem to agree that it is inappropriate to discount minority shares simply because they are minority shares. On the other hand, most courts (even those that reject minority discounts) also recognize that it is sometimes appropriate to apply a marketability discount particularly in situations in which the marketability discount would apply to all the shares, including shares from the control block if they were to be sold. ${ }^{15}$

\section{The (Non) Relationship of Discounts and Premiums}

As should be apparent from the foregoing, there is no formal mathematical relationship between a control premium and a minority or marketability discount. In other words, there is no reason to think that the discount (if any) suffered by a minority shareholder trading in the open market is somehow offset by an equal gain to a controlling shareholder. ${ }^{16}$ Perhaps more to the point, one can easily imagine that in a perfectly fair market a controlling shareholder would still be able to command a premium in a sale of control.

The lack of a relationship is even more apparent in connection with a marketability discount. There is absolutely no reason to think that a controlling shareholder can somehow exact a gain in direct proportion to the difficulty that a minority shareholder has in selling a few shares. Indeed, in the case of an actively traded publicly company one would not normally expect shares to trade at any discount at all except in the sense that a controlling shareholder could command a higher price in a sale of control. To be sure, it may be that a controlling shareholder is able to command a larger than normal control premium because the buyer anticipates looting the corporation. And in that case the additional premium may be equal to the additional gain expected by the buyer. In other words, a minority discount is not the reciprocal of a legitimate control premium. ${ }^{17}$

Moreover, and more important, there is no reason to presume that sellers and buyers of control routinely conspire to cheat minority shareholders. And even if sellers of control often do attempt to exact an additional inappropriate premium it is far from clear that they can command all of the inappropriate gain that the buyer might be able to loot from the corporation. Indeed, a buyer of control would ordinarily be quite reluctant to pay any such bribe because (1) the

\footnotetext{
${ }^{15}$ At least twelve states clearly approve of a marketability discount in appropriate situations, whereas only seven states clearly reject such a discount. See Appendix.

${ }^{16}$ Moreover, for every selling shareholder who suffers a discount there is a buying shareholder who enjoys a bargain.

${ }^{17}$ Nevertheless, professional business appraisers often figure the control value of a company and then apply a minority or marketability discount to the control value to determine the value of public shares. Indeed, there is some authority in Delaware for this approach. See Kleinwort Benson, Ltd. v. Silgan Corp., 1995 Del.Ch.LEXIS 75. But see Hodas v. Spectrum Technology, Inc., 1992 Del.Ch.LEXIS 252.
} 
minority might sue and (2) the buyer might be required to pay a similar premium to the minority in the event of a subsequent cashout merger. In other words, the buyer may end up paying twice. Thus, there is no reason to think that buyers will often agree to pay more than a legitimate control premium even if sellers try to negotiate for one. Indeed, the payment of a premium that is out of line with premiums in comparable transactions may operate as a signal to the market that something is awry and may invite a lawsuit.

Thus, it seems fair to presume that in the usual case a premium for control arises because a controlling shareholder has a legitimate right to dictate (and change) business policies. Sometimes a premium for control may be enhanced by the prospect of looting the subject company. But there is no reason to think that the courts cannot identify such cases when they arise and adjust the appraisal price accordingly. ${ }^{18}$

\section{A Short History of Premiums in Appraisal}

In retrospect, it is fairly easy to see how the courts came effectively to presume that a control premium should routinely be added as an element of value. The problem can be traced back to 1983 when the Delaware Supreme Court handed down its landmark decision in Weinberger v. UOP, Inc. ${ }^{19}$ Among other things, Weinberger held that appraisal should typically be the exclusive remedy in a dispute over fairness of merger price and that an appraisal court (consistent with 1981 amendments to DGCL §262) should consider all relevant factors in determining value. Thus, the court held that an appraisal court should consider any techniques or methods that are generally acceptable in the financial community. Specifically, the Weinberger court held that the appraisal court should have considered evidence based on discounted cash flow and premiums in comparable transactions. ${ }^{20}$

Following Weinberger, the Delaware Supreme Court went on to hold in Revlon v. MacAndrews \& Forbes Holdings, Inc., ${ }^{21}$ that in a situation in which a company is up for sale, the

\footnotetext{
${ }^{18}$ John Coates has also noted that control premiums may come from a variety of sources and has suggested that because the courts may find it difficult to parse these sources the respondent company in an appraisal action should bear the burden of proving that some portion of a premium is attributable to gain from the transaction. John C. Coates, IV, "Fair Value” As an Avoidable Rule of Corporate Law: Minority Discounts in Conflict Transactions, 147 U. Pa. L.Rev. 1251, 1351-1352 (1999). The ultimate conclusion here is quite different in that I would characterize all gains from (subsequent) changes in business policy as excludable gain from the transaction, thus leaving only true discounts to be remedied in appraisal and suggesting that the burden should be on the dissenters as long as the transaction has been properly negotiated or ratified by the minority.

${ }^{19} 457$ A.2d 701 (Del 1983).

${ }^{20} I d$. at 712-13. Although it could be argued that basing appraisal price in part on premiums in comparable transactions is equivalent to awarding some or all of the (percentage) gain from the transaction, it is also true (as the Weinberger court suggested) that part of the value of a company inheres in its potential as a takeover target (unless of course the company is utterly takeover proof). The use of discounted cash flow (DCF) (rather than GAAP earnings) was also revolutionary (even though standard practice in the financial community) because it is fundamentally inconsistent with notion that a non controlling shareholder cannot dictate distributions. To be sure, it is fair to presume that the shareholders will eventually receive distributions equal to the value of the company, but DCF is based on the idea that the corporation will distribute available cash as soon as it becomes available.
}

21506 A.2d 173 (1986). 
board of directors has a duty to seek the highest price possible for the benefit of all the stockholders and cannot favor one bidder over another because of other considerations. ${ }^{22}$ In Cavalier Oil Corp. v. Harnett, ${ }^{23}$ the court held in the context of a short form merger that it is inappropriate to apply a discount to minority shares simply because they are minority shares, suggesting to some that minority shareholders should be entitled to all elements of value that may be attributable even to control shares. And in Rapid-American Corp. v. Harris, ${ }^{24}$ the Delaware Supreme Court held that in the appraisal of a parent company that owned 100 percent of the stock of three operating subsidiaries, the parent should be valued on the basis of the combined control value of the operating companies because the parent was in a position to sell control if it chose to do so. ${ }^{25}$

On the other hand, the decisions that seem to support minority entitlement to some share of a control premium cannot be read in isolation. There are just as many decisions that cut the other way. For example, immediately following Weinberger, the Delaware Supreme Court held in Rosenblatt v. Getty Oil Co. ${ }^{26}$ that a majority shareholder in a cashout merger need not reveal the highest price it would be willing to pay simply because it controls the subsidiary and owes a fiduciary duty to the minority. Then, in Paramount Communications, Inc. v. Time Inc., ${ }^{27}$ the Delaware Supreme Court held that a Revlon duty to maximize ${ }^{28}$ does not arise in a so-called strategic merger, in which two widely held companies become one, and no one individual or discrete group buys or sells control. And in Thorpe v. CERBCO, Inc., ${ }^{29}$ the Delaware Supreme Court held that a controlling stockholder has the right to sell its shares at a premium as long as the premium is not diverted from the corporation. ${ }^{30}$

\footnotetext{
${ }^{22}$ See also Arnold v. Society for Savings Bancorp, Inc., 650 A.2d 1270 (Del.1994) (shareholder is entitled to premium where transaction eliminates potential for further premium); Paramount Communications, Inc. v. QVC Network, Inc., Del. Supr., 637 A.2d 34, 42-43 (1994) (same).

23564 A.2d 1137 (Del. 1989).

${ }^{24} 603$ A.2d 796 (Del. 1992).

${ }^{25}$ This reasoning is peculiar in that any company could form one or more wholly-owned subsidiaries and transfer operating assets to them. Thus, Rapid-American was either based on the happenstance of the corporate structure of the company or it should be seen as applying to all appraisal proceedings. For a similar observation, see Miller $v$. Agranoff, 2001 Del.Ch.LEXIS 71, at *51, note 45.

${ }^{26} 493$ A.2d 929 (Del. 1985).

27571 A.2d 1140 (Del. 1990).

${ }^{28}$ I use the phrase "duty to maximize" to distinguish this aspect of Revlon from numerous other aspects such as the intermediate level of scrutiny. See Arnold v. Society for Savings Bancorp, Inc., 650 A.2d 1270 (Del. 1994)(citing Lawrence A. Cunningham \& Charles M. Yablon, Delaware Fiduciary Duty Law After QVC and Technicolor: A Unified Standard (and the End of Revlon Duties?), 49 Bus. Law. 1593, 1593-94 (1994) as "noting inappropriateness of such colloquialisms as "Revlon duties" and "Revlon-land" in arguments before [the Delaware courts]").

${ }^{29} 676$ A.2d 436 (Del. 1996).

${ }^{30}$ It should be noted that none of these were appraisal cases and that it could be argued that the standard of valuation to be applied in an appraisal proceeding has been developed to reflect special considerations in the context of
} 
In McMullin v. Beran, ${ }^{31}$ the Court of Chancery held that no Revlon duty to maximize arises when a parent company decides to sell a controlled subsidiary for cash even though it could possibly have obtained a higher price in a differently structured transaction. In so holding, the court noted that a change in control arises when the shareholders lose a further opportunity to participate in a change of control premium, ${ }^{32}$ and that Revlon does not apply to situations in which control of the company rests with a single controlling shareholder instead of the public. ${ }^{33}$ The Delaware Supreme Court reversed, holding that even in the absence of a change of control (narrowly defined), there is still a duty to determine whether the deal maximizes shareholder value so that minority shareholders may decide whether to seek appraisal. ${ }^{34}$ To be sure, the court characterized the cause of action primarily as one involving the board's failure to inform itself and the minority. ${ }^{35}$ But the court also characterized the subject of the required inquiry as the determination "whether the merger consideration equaled or exceeded [the] appraisal value of the company as a going concern." 36 Thus, although McMullin is not itself an appraisal case, it is quite clear that the board must consider the appraisal standard of value and that the courts will certainly do so in reviewing whether the board has done its job. ${ }^{37}$ Even if there were some doubt about whether appraisal value includes a control premium, there is no doubt that maximizing value implies obtaining the highest possible premium. Moreover, there is no reason for a shareholder to seek appraisal unless the appraisal price is likely to be higher than the merger price. And if the merger price involves any premium at all, which it almost invariably does, presumably the reason for seeking appraisal is to obtain a still bigger premium. ${ }^{38}$

transactions that give rise to appraisal. These special considerations have never been articulated by the courts however.

${ }^{31} 1999$ Del.Ch. LEXIS 227.

${ }^{32}$ See Equity Linked Investors, LP v. Adams, 705 A.2d 1040 (Del.Ch. 1997). See also McMullin v. Beran, 2000 Del. LEXIS 481, at*17 (referring to "final stage" transaction).

${ }^{33}$ Mendell v. Carroll, 651 A.2d 297 (Del. Ch. 1994).

${ }^{34}$ McMullin v. Beran, 2000 Del. LEXIS 481.

${ }^{35}$ The court expressly declined, however, to establish a new disclosure standard where appraisal is an option, citing Skeen v. Jo-Ann Stores, Inc., 750 A.2d 1170 (Del. 2000).

${ }^{36} I d$. at $* 31-* 32$.

${ }^{37}$ Indeed, the McMullin court mentions appraisal eleven times in the opinion and refers to maximizing value fourteen times.

${ }^{38}$ See also Gilbert v. M.P.M. Enterprises, Inc., 731 A.2d 790 (Del. 1999) (offers to purchase need not be given any weight in absence of evidence that they relate to going concern value of company, "fair merger price in the context of a breach of fiduciary duty claim will not always be a fair value in the context of determining going concern value"). In all fairness, the McMullin court's focus on appraisal may have been necessitated by a concern about materiality in that unless the minority stockholders could do something with the information disclosed to them, it would be futile to require the board even to review the deal. McMullin at $* 22$. The court does note, however, the possibility that the stockholders could have sought an injunction. McMullin at *11. Compare Santa Fe Industries, Inc. v. Green, 430 U.S. 462 (1977); Virginia Bankshares, Inc. v. Sandberg, 501 U.S. 1083 (1991). 
Whatever doubt was left after McMullin that the standard of value in a Delaware appraisal proceeding includes a control premium was put to rest in Agranoff v. Miller. ${ }^{39}$ Agranoff involved the valuation of shares purchased in violation of a stockholder agreement in order to determine the price at which the defendant would be required to sell them to the plaintiff. Agranoff was not an appraisal case, but because of doubts about the standard of value to be applied, the court determined the value of the shares two different ways: (1) based on fair market value principals that would be used in a context other than an appraisal proceeding and (2) based on the "appraisal-unique" fair value standard. ${ }^{40}$ As the court stated, comparable companies analysis builds in a minority discount (in that it is based on prices at which minority stockholders trade small quantities of shares) that must be corrected by adding back a premium for control in an appraisal proceeding. ${ }^{41}$ And indeed, the court found that while the fair market value of the shares was $\$ 41.02$ (without any discount or premium), the appraisal value was $\$ 51.13$ (reflecting a 30 percent control premium according to the court). ${ }^{42}$ Thus, there is simply no doubt that the Agranoff court understood that the appraisal remedy reflects unique policy values. ${ }^{43}$ The Agranoff court struggled somewhat with the question whether premiums in comparable transactions arose because of what might be thought of as the inherent value of control (which may or may not be an appropriate element of appraisal value) as opposed to planned changes in business strategy for the target (which clearly are not an appropriate element of appraisal value). In the end, the court reasoned that even though the averaging of comparable company data would likely eliminate merger gains, a reduction of the average premium from 40 percent to 30 percent would help assure that only inherent control value was included..$^{44}$

This cursory review of Delaware caselaw reveals that there are two distinct questions to be addressed in connection with premiums in appraisal proceedings. First, is it appropriate to add a premium at all in the context of an appraisal proceeding even if there is a change of control? Although this issue appears to be well settled in the affirmative, the fact remains that the plaintiffs in an appraisal proceeding are by definition dissenters who seek the value of their shares prior to any gain or loss from the transaction. To be sure, as the Delaware court suggested in Weinberger, every company is potentially for sale and thus part of the value of every company is a generic premium for control, as opposed to a specific premium for control that may be offered by a bidder with specific plans for the target. The latter sort of deal-specific premium presumably should not be part of an appraisal award. ${ }^{45}$ But even if one can get cozy with the idea of awarding a premium in a change of control transaction, it does not follow that it makes

\footnotetext{
${ }^{39} 2001$ Del.Ch.LEXIS 71.

${ }^{40} I d$. at $* 20-* 29$.

${ }^{41} I d$. at $* 48-* 54$.

${ }^{42} I d$. at $* 57-* 59$.

${ }^{43} I d$. at $* 23$.

${ }^{44} I d$. at $* 54$, note 49 .

${ }^{45}$ The courts have done little to distinguish these two types of premiums though in fairness it could be said that averaging premiums paid for comparable companies may have the same effect.
} 
sense to award a premium in (say) a going private merger in which the controlling shareholder remains in control and where there was never any prospect of a sale of control. ${ }^{46}$ Thus, the second question -- and the focus here -- is should a premium for control be added even if it is clear that the dissenters could not reasonably have expected a premium under any other circumstances. $^{47}$

\section{Discounts and the Law of Appraisal}

Outside of Delaware, most authorities appear to agree that valuation in an appraisal proceeding should be based on the transaction that occurs and not on a hypothetical transaction that might have carried a higher or lower price. Thus, it would seem to follow that if there is no sale of control and no possibility of a sale of control, it is inappropriate to add a control premium to the value of the firm as a going concern.

\section{ALI Principles of Corporate Governance}

Section 7.22 of the ALI Principles of Corporate Governance (the "PCG") (entitled Standards for Determining Fair Value) provides that the fair value of shares in an appraisal proceeding should be determined "without any discount for minority status or, absent extraordinary circumstances, lack of marketability." It also provides, however, that value should be determined "in the context of the transaction giving rise to appraisal." Comment (d) to this section makes it clear that "This standard does not necessarily imply...that fair value should be determined by the presumed outcome of a hypothetical competitive auction." The Comment notes that "In general, the justification for disregarding the auction standard is strongest in the context of parent-subsidiary transactions... where the parent has long held control of the subsidiary and had consistently indicated its intent not to sell." 48 As the comment notes, the same result should obtain where a shareholder who has held outright control over a long period of time seeks to eliminate the minority in order to rationalize its corporate structure. ${ }^{49}$ Thus, it seems quite clear that it is inappropriate to include a control premium in an appraisal price where there is no possibility that that premium could be obtained, because there is no possibility that control would be sold, as in the context of a cash-out merger in which the controlling group has made known that it will not consider selling out to a third party. ${ }^{50}$

\footnotetext{
${ }^{46}$ To be sure, Weinberger itself was such a case, but the majority therein was held liable for a breach of fiduciary duty in having failed to deal fairly with the minority.

${ }^{47}$ Interestingly, the federal courts have recognized a parallel distinction in connection with materiality determinations under the federal securities laws. Although, it is well settled that a fact need not be so important as to change the outcome of a vote or transaction in order to be material, the courts recognize that when a fact cannot make a difference it is not material. See Virginia Bankshares, Inc. v. Sandberg, 501 U.S. 1083 (1991).

${ }^{48} 2$ PCG $\$ 7.22$, Comment (d) at 321 (student edition).

${ }^{49} I d$.

${ }^{50}$ The PCG further suggests that in some cash-out situations, it may even be appropriate to impose a marketability discount, stating that "Only if it was clear to shareholders when they acquired their shares that, based on the corporation's statements, acts, and other circumstances, the corporation would not be sold" would it be appropriate
} 


\section{ABA Model Business Corporation Act}

The most recent revisions to the Model Business Corporation Act, which were promulgated in November 1998, are consistent with the approach of the ALI although less well developed. As stated in MBCA §13.01, Comment (2), the MBCA "adopts the accepted view that different transactions and different contexts may warrant different valuation methodologies." ${ }^{51}$ The comment further states that although a discount for minority status is inappropriate in transactions that affect the whole corporation, it may be appropriate where only some shareholders are affected. ${ }^{52}$ It bears noting that the MBCA has vacillated on whether there should be a market exception to the right of appraisal. A market exception was added in the 1960s, was limited in the 1970s, was eliminated with the revision of 1984, and was reintroduced in 1998. Although reliance on market price is seen by most courts and commentators as equivalent to recognizing an imbedded minority discount, the MBCA clearly recognizes market price as fair as long as the market is reasonably deep and deal in question does not raise a duty of loyalty problem. Thus, it is not entirely clear what position the MBCA takes. And perhaps as a result, some model act states continue to rely heavily on market price in appraisal proceedings. ${ }^{53}$

\section{Delaware Law}

Despite recent cases to the contrary, Delaware law has traditionally been consistent with the approach of the PCG and the MBCA (at least in actions for damages) in recognizing that a shareholder has no right to expect a price based on a higher price that might be paid in a different transaction. ${ }^{54}$ This flexible approach to valuation, which recognizes that fair price must be based

for management to acquire the business "based on either the firm's current market or going concern value...." Id. at 323. For a recent case relying heavily on the PCG in this connection, see Lawson Mardon Wheaton, Inc. v. Smith, 315 N.J.Super. 32, 716 A.2d 550 (1998) (dissenters exploited restructuring undertaken for tax advantages; marketability discount upheld), rev'd, 734 A.2d 738 (N.J. 1999) (no extraordinary circumstances present).

5154 Bus. Law. 256 (1998).

${ }^{52} I d$. at 256 - 257. The comment cites as examples of situations in which a discount might be appropriate (1) a voluntary right of appraisal in connection with an amendment to the articles of incorporation or (2) setting a price at which the company or a remaining stockholder might buy out a stockholder who has sought voluntary dissolution on grounds of oppression or deadlock or some similar rationale under §14.34. Indeed Official Comment 4(b) to $\$ 14.34$ states that a discount may be appropriate because the complaining stockholder would only have been able to sell to a third party at a discount. Caselaw in many states is to the contrary. See Appendix. It bears noting that the 1998 amendments to the MBCA eliminated appraisal in connection with amendments to the articles of incorporation that affect the financial rights of a class of stockholders.

${ }^{53}$ See Armstrong v. Marathon Oil Co., 32 Ohio St. 3d 397, 513 N.E.2d 776, 785-86 (1987) (willing buyer-seller test should focus on the specific shares held by the dissenter).

${ }^{54}$ See Rosenblatt v. Getty Oil Co., 493 A.2d 929, 942 (Del. 1985); Sterling v. Mayflower Hotel Corporation, 93 A.2d 107 (Del. 1952). See also Rothschild Int'l. Corp. v. Liggett Group Inc., 474 A.2d 133, 137 (Del.1984) (equating damages standard with appraisal standard). For appraisal cases stating that dissenters are not entitled to a higher price that might be obtained in a differently structured transaction, see Rapid-American Corp. v. Harris, 603 A.2d 796 (Del. 1992); Bell v. Kirby Lumber Corp., 413 A.2d 137 (Del. 1980). But see In re Shell Oil Co., 607 A.2d 1213 (Del. 1992) (approving use of arguable evidence of liquidation value and rejecting addition of control premium). See also Paskill Corp. v. Alcoma Corp., 747 A.2d 549 (Del. 2000) (appraisal price should reflect actual 
on the transaction that happens and not on some other transaction that might have happened, is consistent with the broader principle that where the board decides to sell the company it must maximize the price obtained, but where the board decides to merge the company with another company in a strategic combination in which control will remain in the hands of existing shareholders, it need not do so. ${ }^{55}$ Moreover, Delaware has implicitly recognized that the price approved by a fully informed majority of the minority should be presumed to be fair. ${ }^{56}$ Even in the context of the idealized appraisal remedy, Delaware law seems to freight in consideration of the transaction despite claims to the contrary, for example by considering premiums paid in comparable transactions. ${ }^{57}$

On the other hand, Delaware long ago also recognized the danger of imbedded discounts and rejected market price as having any presumptive weight in an appraisal proceeding. ${ }^{58}$ To be sure, Delaware also has a market exception in its appraisal statute, but it is quite different from the one in the MBCA in that it only applies where the stockholder receives shares in the surviving company or shares of another publicly traded company or cash in lieu of fractional shares. ${ }^{59}$ Thus, leaving aside fractional shares, the only situation in which the market exception applies is one in which the there is little reason to worry about an imbedded discount or a lost chance at a premium.

Cavalier Oil itself makes it clear that the appraisal remedy is designed to view the company as a going concern and "is not intended to reconstruct a pro forma sale but to assume that the shareholder was willing to maintain his investment position, however slight, had the merger not occurred. ${ }^{60}$ Moreover, the issue of minority discounts arose in Cavalier Oil because of Tri-Continental Corp. v. Battye ${ }^{61}$ in which the Delaware Supreme Court held that it is appropriate to apply a discount in a situation in which the discount affects all of the shares of the company. Far from rejecting Tri-Continental, the Cavalier Oil court held that it is perfectly appropriate to apply a discount in such a setting as long as the discount is not applied at the shareholder level. As the court pointed out in Cavalier Oil failure to accord full value to minority shares may result in a windfall for the majority. ${ }^{62}$ Clearly, the court was more

business policies); Cede \& Co. v. Technicolor, Inc., 684 A.2d 289 (Del. 1996) (same even though policies instituted after acquisition of control but before cashout merger eliminating minority).

${ }^{55}$ See Paramount Communications, Inc. v. QVC Network, Inc., 637 A.2d 34 (Del. 1994).

${ }^{56}$ See Weinberger v. UOP, Inc., 457 A.2d 701 (Del 1983). See also Rosenblatt v. Getty Oil Co., 493 A.2d 929 (Del. 1985) (majority shareholder need not disclose proprietary information about reservation price to minority).

${ }^{57}$ See Weinberger v. UOP, Inc., 457 A.2d 701, $712-714$ (Del 1983).

${ }^{58}$ See Chicago Corp. v. Munds, 20 Del. Ch. 142, 172 A. 452 (1934). See also Smith v. Van Gorkom, 488 A.2d 858, 876 (1985) ("publicly-traded stock price is solely a measure of the value of a minority position and, thus, market price reflects only the value of a single share").

${ }^{59}$ DGCL $§ 262(b)$.

${ }^{60} 564$ A. $2 \mathrm{~d}$ at 1144.

${ }^{61} 74$ A.2d 71 (Del. 1950). 
concerned about the majority appropriating value from the minority than it was about conferring the benefits of a control premium on minority shareholders who otherwise would never enjoy it. That in itself would be a windfall.

There is nothing in Cavalier Oil about control premiums. Indeed, the case quite explicitly states that the appraisal remedy assumes that the shareholder was willing to maintain his investment position. So how is it that the case has come to be cited for the notion that the minority is entitled to a control premium in appraisal? The following passage from Agranoff affords a clue:

As a practical matter, correction of a minority discount requires the court to add back a control premium to the value of the enterprise, and to spread that premium equally across all the enterprise's shares. The resulting value for a minority share is thus not what would be considered "fair market value" in valuation terms, but an artificial value that reflects policy values unique to the appraisal remedy. In simple terms, those values may be said to consist of this proposition: if a majority stockholder wishes to involuntarily squeeze-out the minority, it must share the value of the enterprise with the minority on a pro rata basis. ${ }^{63}$

\section{In support, the Agranoff court notes:}

In Cavalier Oil Corp. v. Harnett, Del.Supr., 564 A.2d 1137 (1989), the Supreme Court held that this court was correct in refusing to apply marketability and minority discounts in appraising the stock held by a minority stockholder in a small corporation. In so ruling, the Supreme Court embraced the view "that the objective of a section 262 appraisal is "to value the corporation itself, as distinguished from a specific fraction of its shares as they may exist in the hands of a particular shareholder'..." Id. at 1144 (quoting Court of Chancery opinion without citation) (emphasis in original). the Supreme Court explained the policy justification for this approach as follows:

Discounting individual share holdings injects into the appraisal process speculation on various factors which may dictate the marketability of minority shareholdings. More important, to fail to accord to a minority shareholder the full proportionate value of [the petitioner'] shares imposes a penalty for lack of control, and unfairly enriches the majority shareholders who may reap a windfall from the appraisal process by cashing out a dissenting shareholder, a clearly undesirable result. 564 A.2d at $1145 .{ }^{64}$

It is crystal clear that the Agranoff court believes that a control premium comes from a minority discount. Indeed, later in the opinion the court discusses the sources of premiums at some length, finding (in essence) that premiums may come from (1) the potential for looting, (2) the right to direct business policies, or (3) synergistic gains. The court holds that only synergistic gains must be excluded (as gain from the transaction) and rules that the market average control premium (40 percent) should be reduced by ten percent (to 30 percent) as a rough adjustment for the disallowed portion of the premium. ${ }^{65}$

\footnotetext{
${ }^{62} 564$ A.2d at 1144.

${ }^{63} 2001$ Del.Ch.LEXIS at $* 23$.

${ }^{64} I d$.

${ }^{65}$ Id. at $* 48-* 55$ (discussing Coates article at length). The court also notes that another source of premiums may be overpayment by bidders, but it does not indicate whether overpayments should be included or excluded under the statutory standard.
} 
There is simply nothing in Cavalier Oil that indicates that minority shareholders should be entitled to any share of a legitimate control premium in an appraisal proceeding. Indeed, the quoted portions of Cavalier Oil quite clearly suggests the opposite: It states that the goal of appraisal is to determine the per share value of the entire corporation and not the value of specific shares -- presumably whether they are minority shares or control shares. It further states that discounting for minority status injects an element of speculation into the process. The same is true of the addition of control premium. Indeed, the need to arbitrarily shave off some of the premium proves the point.

Agranoff specifically addresses allowed and disallowed sources of premiums, stating that:

\begin{abstract}
If the policy basis for the correction for a minority discount is to insure that the minority that is squeezed out receives their proportionate value of the enterprise regardless of their minority status, it is unclear why the court should parse the available data about control premiums paid in an impossible attempt to determine the factors that contributed to the total premiums paid and their relative economic importance. Such data, after all, is not about value derived from the transaction giving rise to appraisal rights -- that is, the value that cannot be considered under $\$ 262$. Rather, one hopes that the data reflects a diversified information set about the typical premiums that acquirors will pay for control positions, which can be compared with some reliability to the price at which minority blocks sell. Given the policy approach taken in Cavalier, it is not apparent why it is critical to ensure that minority stockholders do not receive their proportionate share of the value that would likely be paid by a hypothetical acquiror in the event that the acquiror could attain control of the entity under its existing business plan. Whatever the acquiror's motives, that price in fact reflects the increased value the acquiror places on a control block of the company's shares over the value the market places on a minority block. Whatever the acquiror's motives, the acquiror (perhaps as a result of hubris) expects to derive value (from the employment of relatives, synergies, or other gains) that will justify the premium paid. ${ }^{66}$
\end{abstract}

As this passage reveals, the idea that market prices reflect an inherent minority discount and that control premiums derive in part from the elimination of this discount requires the court to consider whether some part of the premium represents gain from the transaction and must be disallowed, revealing a fundamental contradiction. First the court assumes that premiums do not include transaction specific gains because the data is averaged (itself a questionable assumption). ${ }^{67}$ Then the court dismisses the need to exclude a pure control premium (one that would be paid even in the absence of a plan to change the business) on the grounds that acquirors generally expect to increase the value of the target business. Clearly these propositions cannot both be true. Yet the Agranoff court reasons from this foundation to the conclusion that premiums should be assumed to come from all possible sources and that the burden should be on corporation to prove the amount of the premium attributable to excludable gains. ${ }^{68}$ The idea seems to be that most sources of premiums are part of the going concern value of the corporation

\footnotetext{
${ }^{66}$ Id. at $* 50-* 51$ (footnotes omitted).

${ }^{67}$ The court cites several studies indicating that premiums in synergistic mergers appear to be no greater than premiums in other mergers. $I d$.

${ }^{68}$ Citing John C. Coates, IV, “Fair Value” As an Avoidable Rule of Corporate Law: Minority Discounts in Conflict Transactions, 147 U. Pa. L.Rev. 1251, 1274 -1278, 1350-1352 (1999).
} 
that belongs to all shareholders. In other words, a little corruption in the data is tolerable. Yet in the end the court shaves off a random ten percent of the premium.

Moreover, there is in fact a very good reason to exclude any part of a premium that might be paid even in the absence of plans to change the business. In other words, there is no reason to assume that all (or even most) mergers are motivated by plans to change the business. Many mergers may well be motivated simply by the desire to escape public ownership. Indeed, several recent Delaware appraisal cases have involved cashout mergers designed to reduce the number of shareholders below 75 so as to permit the company to elect S Corporation status under the Internal Revenue Code, ${ }^{69}$ an opportunity that by definition may never be shared with a significant public minority. Even in the absence of some such standardized reason to cash out a minority, however, it is far from clear that minority shareholders have any expectation of participation in an ownership interest in any conventional sense of the word. As I have argued elsewhere, it may be that most companies go public not because they need capital but rather because they seek access to market pricing, liquidity, the ability to use stock as acquisition currency and to issue compensatory stock options, and other benefits of public ownership. If so, it is entirely possible that some companies ultimately find that these benefits are not worth the trouble of being publicly traded and simply choose to return to private ownership. Moreover, if shareholders recognize that these are valid reasons for a company to issue stock, it is quite arguable in most circumstances other than sales of control that minority shareholders would and should be satisfied with any return at least equal to a market rate of return.

On the other hand, it is quite clear that some premium would be paid in any properly negotiated cashout transaction even if the minority could not force a sale of control and even if the majority has no plans to change the business. ${ }^{70}$ The majority would not propose a costly merger unless it perceived some sort of gain, and the minority would therefore insist on some sort of payment over and above fair market value. Still, the fact that the majority perceives a gain does not mean that the gain is part of the going concern value of the company before the cashout. After all, the stated goal of the appraisal remedy is to give the shareholder the value of what has been taken away. In other words, the standard is out-of-pocket not benefit-of-the-bargain.

How should this inherent contradiction be resolved? The answer is that the contradiction arises because of a misreading of Weinberger. Weinberger involved the cashout of a large minority interest in which the court found that the majority had breached its fiduciary duty by failing to disclose material facts about the price and how it was negotiated. The court noted that the plaintiffs had forgone appraisal possibly because of the outmoded approach to valuation applied in an appraisal proceeding. The court then went on to hold that the approach to valuation should be the same in appraisal and fiduciary duty cases and that both should consider any widely accepted techniques presumably including those that had been offered in that case (discounted cash flow and premiums in comparable transactions). Finally, the court held that the appraisal remedy should ordinarily be the exclusive remedy for unfairness but that an appraisal

\footnotetext{
${ }^{69}$ See, e.g., M.G. Bancorporation, Inc. v. LeBeau, 737 A.2d 513 (Del. 1999).

${ }^{70}$ One might liken this to an exit fee or redemption premium designed to discourage corporations from going public and going private willy nilly.
} 
court should have the power to award complete relief (such as rescissory damages) in appropriate cases.

On the one hand, Weinberger seems to unify the standard of value to be applied in appraisal proceedings and actions for damages. On the other hand, Weinberger clearly does not hold that additional benefit-of-the-bargain relief is appropriate in all cases. Indeed, Weinberger has not been followed much in connection with its authorization of additional relief for fiduciary duty cases. ${ }^{71}$ But additional relief seems to have found its way into appraisal cases even though Weinberger itself was a fiduciary duty case. Despite the confusion, it seems quite clear that the Weinberger court was saying that an appraisal award should invariably be lower than an award of damages (if appropriate). ${ }^{72}$ Yet the routine addition of a control premium in appraisal cases effectively eliminates the difference between the two, making dismissal-proof appraisal far more attractive than it should be. ${ }^{73}$

\footnotetext{
${ }^{71}$ See, e.g., Cede \& Co. v. Technicolor, Inc., 684 A.2d 289 (Del. 1996). But see PCG §7.22, Reporter’s Note 5.

${ }^{72}$ To be sure, an award of a control premium in appraisal and rescissory damages in an action for damages are two different things. But the monetary difference is an illusory one based on timing. A control premium is forward looking (ex ante) and rescissory damages are backward looking (ex post). An award of rescissory damages may thus be greater, but it may also be smaller. An award of a control premium thus carries less risk and may even include interest.
}

${ }^{73}$ There is indeed evidence that appraisal has become more popular in recent years. But presumably negotiation is preferable to litigation. Accordingly, assuming that cashout mergers should not be banned altogether because they are sometimes desirable (which now seems incontrovertible), we should presumably seek to devise self-enforcing mechanisms to assure that they are carried out on terms that the parties would find acceptable. Given that a minority can invariably command a premium in a cashout merger even in the absence of a change of control or majority plans to change the business, minority shareholders would presumably prefer to negotiate a price rather than have it set by an appraisal court without the prospect of any premium. Thus, precluding the inclusion of a control premium in properly negotiated transactions will encourage fair dealing up front and discourage the routine institution of appraisal proceedings. Moreover, it is entirely possible that premiums differ depending on the size of the minority (as studies indicate is the case in connection with tender offers), thus injecting even more uncertainty into the appraisal process and arguing even more strongly for a self-enforcing regime. It does not appear that the courts have considered the possibility of differing premiums in appraisal proceedings (perhaps because to do so would amount to the appraisal of particular shares). Nevertheless, if it is the case that premiums tend to decrease as the majority interest increases (as seems likely), then appraisal would tend to be more attractive in cases in which the minority interest is smaller thus exacerbating any holdout problems. On the other hand, one could also argue that the last shareholders to give up their shares are the ones who perceive the highest value in those shares (although to consider any such subjective element of value would also run afoul of the prohibition on valuing particular shares). Although the question of whether to include a control premium as an element of value appears to be settled in sale of control cases, it is also often difficult to determine precisely what percentage of shares constitutes control and thus to know whether a particular company is potentially a target and whether a premium for control should be added. Moreover, it is unclear whether a remaining minority interest in a two-step tender offer and cashout combination should be able to command a premium in appraisal while a similar minority interest of longer standing should not be able to do so. These issues could all be eliminated by a rule generally precluding the consideration of control premiums in properly negotiated transactions. One might even argue that the appraisal remedy should be eliminated altogether for public companies if the transaction is carried out using certain procedural safeguards such as a minority vote. One might well ask, however, whether there is any point in retaining the appraisal remedy at all if it only applies in situations in which a fiduciary duty case would lie. The answer is that appraisal may still make sense as a check for cases in which the minority might be inclined even voluntarily to accept too little because of minority or marketability discount. That is roughly the approach taken by the MBCA (since 1999), although the MBCA retains appraisal in cases in which the surviving corporation has a 20 percent or greater pre-merger interest in the target corporation. 
In short, the Agranoff approach is totally backwards or at the very least unworkable. The better view is that most sources of premiums other than those that arise from looting are excludable in an appraisal proceeding. And the courts can presumably deal with those cases when they arise. Accordingly, the burden of proof should be on dissenters if for no other reason than that most (if not all) sources of merger premiums are excludable. If the only reason for adding a premium to the appraisal price is to eliminate a minority discount (if any), then the question to be addressed should be whether the merger price was in fact affected by such a discount.

Even if Delaware law requires that a premium for control be considered an element of value, it is far from clear that other states would or should follow its lead. The Delaware approach is an outgrowth of changes to the Delaware statute in 1981 (mandating that the courts consider "all relevant factors" in determining fair value) and the interpretation of that language by the Delaware Supreme Court in Weinberger v. UOP, Inc., ${ }^{74}$ holding that premiums in comparable transactions as well as any breaches of fiduciary duty in the negotiation of the transaction should be considered by future appraisal courts. Weinberger arguably was the culmination of a series of cases and statutory changes under which Delaware undertook to scrutinize mergers and acquisitions in order to enhance the position of public shareholders because of the perception that Delaware law was too management friendly. Some had argued that corporation law as it relates to publicly traded corporations should be supplanted by federal law. Thus, Delaware reacted by augmenting protections available to public shareholders. ${ }^{75}$ In any event, it is clear that Delaware caters to publicly traded companies. Indeed, Delaware has expressly declined to engage in any sort of flexible analysis designed to consider the peculiar needs of closely held corporations that do not elect formal close corporation status. ${ }^{76}$ Moreover, Delaware favors mergers, acquisitions, and takeovers, both friendly and hostile. For example, Delaware has the least restrictive takeover law of any state. ${ }^{77}$ It also imposes a requirement on the board of directors of a target company, once it is apparent that the company will be sold, to sell the company to the highest bidder, a rule that is enforced through an enhanced level of scrutiny (and which has been expressly rejected by other states. ${ }^{78}$ ). In addition to the fact that Delaware is quite liberal with regard to valuation in appraisal, the appraisal remedy in Delaware is nonexclusive. ${ }^{79}$ In contrast, many other states have statutes that provide that the appraisal

\footnotetext{
${ }^{74} 457$ A.2d 701 (Del 1983).

${ }^{75}$ See William T. Allen, The Pride and the Hope of Delaware Corporation Law, 25 Del. J. Corp. L. 70 (2000).

${ }^{76}$ See Nixon v. Blackwell, 626 A.2d 1366 (Del. 1993). See also Toner v. Baltimore Envelope Co., 304 Md. 256,498 A.2d $642(1985)$.

${ }^{77}$ See Norman E. Veasey, et al., The Delaware Takeover Law: Some Issues, Strategies, and Comparisons, 43 Bus. Law. 865 (1988).

${ }^{78}$ See Indiana Code Annotated §23-1-35-1 (expressly rejecting Delaware case law); Maryland Code, Corporations \& Associations §2-405.1(1999) (same effect). On the other hand, some states (most notably Oklahoma) have chosen to follow Delaware law quite closely.

${ }^{79}$ See Cede \& Co. v. Technicolor, Inc., 634 A.2d 345 (Del. 1993).
} 
remedy is the only means by which a stockholder may challenge the terms of a merger in the absence of fraud or illegality and in some cases even if there is fraud or illegality. ${ }^{80}$ Under Delaware case law, on the other hand, one may even argue breaches of fiduciary duty in an appraisal proceeding, which is clearly not allowed in most other states. ${ }^{81}$ In short, Delaware law is different -- arguably because it is designed to address the needs of publicly traded corporations -- and it is not necessarily appropriate for states that seek to serve the interests of their domestic corporations.

\section{Whence Premiums?}

Although one might argue (on a theory akin to the law of conservation of matter and energy) that control value must come out of someone's pocket, the law clearly recognizes that there are some sources of value that belong to controlling shares and that do not represent an appropriation of value from minority shareholders. A controlling shareholder is free within the limits of the law of fiduciary duty to pursue policies that are in the best interest of the controlling shareholder as long as minority shareholders are treated equally. That is, a controlling shareholder may run the corporation however he or she chooses to do so as long as it is in good faith and the benefits enjoyed by the controlling shareholder are not at the expense and exclusion of the minority. ${ }^{82}$ Thus, a majority shareholder may cause the controlled corporation to pay generous dividends ${ }^{83}$ or to withhold dividends and reinvest available $\operatorname{cash}^{84}$ because it suits the controlling shareholder to do so. A controlling shareholder has the right to control and to vote its shares in its own interest. It is not objectionable that the motive may be for personal profit or determined by whim or caprice as long as the controlling shareholder violates no duty owed to other shareholders. ${ }^{85}$ And indeed a controlling shareholder may sell the corporation on terms that it favors even though a differently structured deal might be more to the liking of the minority (assuming, of course, that the buyer agrees). ${ }^{86}$ As I have argued elsewhere, these are all examples of unshareable opportunities, and although they are flavored with conflict of interest, the courts have only intervened when the controlling shareholder has sought to use control for non business purposes $^{87}$ or has visited unnecessary harm on the minority. ${ }^{88}$

\footnotetext{
${ }^{80}$ See MBCA $§ 13.02$ (d) and Comment (5); PCG $\$ 7.24$ and Comment 4 (indicating that 18 states make the appraisal remedy exclusive and that two provide no exceptions even for fraud or illegality).

${ }^{81}$ See Weinberger v. UOP, Inc., 457 A.2d 701 (Del 1983).

${ }^{82}$ Sinclair Oil Corp. v. Levien, 280 A.2d 717 (Del. 1971); Fliegler v. Lawrence, 361 A.2d 218 (Del. 1976). See generally Mary Siegel, The Erosion of the Law of Controlling Shareholders, 24 Del. J. Corp. L. 27 (1999).

${ }^{83}$ See Sinclair Oil Corp. v. Levien, 280 A.2d 717 (Del. 1971).

${ }^{84}$ See Berwald v. Mission Development Company, 185 A.2d 480 (1962).

${ }^{85}$ Bershad v. Curtiss-Wright Corp., 535 A.2d 840 (1987); Emerson Radio Corp. v. International Jensen, Inc., 1996 Del.Ch.LEXIS 100.

${ }^{86}$ McMullin v. Beran, 1999 Del.Ch. LEXIS 227; Mendell v. Carroll, 651 A.2d 297 (Del. Ch. 1994).

${ }^{87}$ Richard A. Booth, The Business Purpose Doctrine and the Limits of Equal Treatment in Corporation Law, $38 \mathrm{Sw}$. L. J. 853 (1984). To be sure, many of these controversies do not give rise to appraisal rights (although under the
} 
The rule could be different. And indeed in some other countries -- such as the UK -- it is. ${ }^{89}$ The law could reflect the presumption that in connection with a sale of control the corporation is likely to be looted. But US law (notwithstanding a few cases to the contrary) generally reflects the judgment that a control premium does not necessarily come from looting. As a matter of policy, US law seems to reflect the judgment that a controlling shareholder or entrepreneur is entitled to found value rather than being required to share it with passive shareholders. ${ }^{90}$

The US rule is clearly preferable if there is reason to think that the courts can detect looting when it occurs or is likely to occur. ${ }^{91}$ The contrary rule effectively throws the baby out with the bathwater by preventing value increasing transfers of control simply because some may turn out to be abusive. By allowing a controlling shareholder to keep the benefits of a sale of control, the law creates (or at least does not destroy) the incentive for business owners to seek out new managers with better ideas. Similarly, there is no explicit rule in the US against partial tender offers in which a hostile bidder may seek a bare controlling interest of a target company even though there is a danger if the offer succeeds that the new controlling shareholder may loot the target and even though the danger of looting may cause shareholders to tender their shares at a lower price than in an any or all offer. ${ }^{92}$ Sauce for the goose is sauce for the gander.

MBCA as it stood prior to 1998 appraisal was broadly available for amendments to the articles of incorporation). Thus, the fact that controlling shareholders have been able to arrogate value to themselves may simply be a reflection of the lack of a remedy for dissenting shareholders. Indeed, it has been argued that the proper function of appraisal is to protect shareholders from fundamental changes that alter the risk characteristics of the company. See Peter V. Letsou, The Role of Appraisal in Corporate Law, 39 B. C. L. Rev. 1121 (1998). And the risk of (permissible) self dealing is part of the risk a shareholder assumes in investing -- especially in a corporation with a controlling shareholder. In other words, the rule that control value should be awarded in an appraisal proceeding may be seen as part of the transaction rather than a universal shareholder right to equal treatment. On the other hand, if the rationale for appraisal is give the shareholder the right to cash out in the event of a risk-altering transaction, one might argue that appraisal should not be available at all in a cash out merger and especially a cash out merger in which an existing controlling shareholder remains in control. The ultimate point, however, is that if appraisal awards the dissenting shareholder some element of value that the shareholder did not enjoy before, it may encourage dissent and discourage economic transactions.

${ }^{88}$ See Jones v. H. F. Ahmanson \& Co., 1 Cal.3d 93, 81 Cal.Rptr. 592, 460 P.2d 464 (1969).

${ }^{89}$ See Emmerich \& Shapiro, Poison Pill Approaches its 15th Birthday, Responses of Other Jurisdictions Support Evidence of Beneficial Effects of Shareholder Rights Plans, New York Law Journal, November 15, 1999, at S8 (describing mandatory offer rules in EU countries).

${ }^{90}$ The American rule also works a certain rough justice for controlling shareholders who assume company specific risk as compared to highly diversified portfolio investors who assume only market risk. To require that such investors be cut in on a sale of control that results from a value increasing transaction unanticipated by the market not only reduces the incentive for controlling shareholders to seek out such transactions, it also confers a windfall on portfolio investors. In other words, it is only fair that controlling shareholders who have assumed extraordinary risk by forgoing diversification be free to capture any premium that results from such a transaction.

${ }^{91}$ See, e.g., Debaun v. First Western Bank \& Trust Co., 46 Cal.App.3d 686 (1975).

${ }^{92}$ Partial tender offers are now rather rare because a competing bidder who offers to buy all of the target shares (and thus eschews both the opportunity to loot the target and accordingly to coerce the target shareholders into tendering) will be encouraged to come forward and will presumably be favored by the target shareholders also because in an 
Moreover, a rule that minority shares are entitled to a premium for control in effect confers a windfall on minority shares that were presumably purchased at a price that reflected the lack of any assurance that the company would ever be put up for sale. Indeed, it has become quite common in connection with initial public offerings for the company to offer a small minority of shares simply to create a liquid public market (perhaps to facilitate the use of stock options as compensation) or to test the waters for a potential future offering or for a variety of other reasons having little to do with raising capital. ${ }^{93}$ In any event, there is no assurance in connection with an IPO that the company will later sell enough additional shares (with enough votes) to expose itself to takeover. ${ }^{94}$ A rule that makes control value available in appraisal thus would discourage legitimate transactions and encourage dissent. ${ }^{95}$

Again, we could adopt a rule that says that a company that goes public must go all the way public and may not gain access to the public market while leaving an outright majority of shares or votes in the hands of a controlling person or group. But there is no such rule on the books. And it is unclear why we should limit the options available to companies that may want to tap the public market for whatever reason. More choice (and private ordering) is presumably better than less unless the potential for abuse is more evident than it is here. After all, if the market does not want to buy into an IPO in which the controlling shareholders decline to give up any control, presumably it will not do so and the offering will fail. In other words, this is an area in which we can confidently let the market decide.

To be sure, there could be situations in which the company has bought back shares so as to concentrate ownership in the hands of the largest shareholders, thus eliminating an existing potential for takeover. Such creeping freezeouts are presumably rare. One would think that they would make news and generate litigation just as greenmail does. Yet there is no evidence of such

offer for all of the target shares the target shareholders avoid the potential for proration under federal tender offer law. Moreover, although prior to the 1980s lack of funding may have necessitated some partial offers, the development of the junk bond market has made large amounts of cash available for ever bigger offers. Thus, partial offers have more or less evolved away because of competition among bidders. In addition, many states have adopted takeover statutes that effectively preclude partial offers without banning them outright. For example, DGCL §203 prohibits any merger or other disposition of assets of a target company for a period of three years after a hostile change in control unless the new controlling shareholder acquired at least 85 percent of the stock of the target company. Oddly enough, it is quite common under mandatory offer rules (such as those in the UK and elsewhere in the EU) for shareholders to receive a combination of cash and stock, which is precisely the result that shareholders fear in a partial offer.

${ }^{93}$ For example, in 36 IPOs during the month of October 1999, the median offering was for just 18 percent of the shares of the issuing company as would be outstanding after completion of the offering.

${ }^{94}$ In addition to the practice of selling a relatively small number of shares, many company sell only lesser voting shares to the public, with insider shares typically carrying five or ten votes per share to one vote per share for those sold to the general public. It is at least arguable that because of evolving practices by which newly public companies insulate themselves from takeover before going public, we should confer similar advantages on existing public companies, one of which may be a clear rule that control value is available under the appraisal remedy.

${ }^{95}$ It is possible that trend toward sale of relatively few shares is an effort to reserve any future takeover premium and in that sense to fine tune the division of returns with public shareholders, which would further suggest that public shareholders are not in fact the ultimate owners of the corporation. 
controversies arising as a result of going private or buyout transactions, perhaps because a program of advance purchasing would clearly run afoul of federal securities law as well as the rule that a control premium may not be exacted at the expense of minority shareholders. In other words, the law can deal with any such abuse when it arises. It is no reason to alter the sensible rule that the standard of value in an appraisal proceeding should reflect the transaction at hand. ${ }^{96}$

There is also a danger that a controlling shareholder, who professes that the company is not for sale at the time of going private, will undergo a change of mind after a decent interval and sell the company at a big gain after all. (As the Church Lady would say: "How convenient.") Again, the law can deal with such cases when they arise. It suffices to say that if the controlling shareholder knew an offer was in the offing, buying up the public shares so as to appropriate the gain would constitute not only a breach of fiduciary duty but also securities fraud. ${ }^{9}$

In the end, even if one insists on referring to the lack of a control premium as a minority discount, it is a minority discount that affects all shares equally, including any shares that the controlling shareholder might desire to sell short of selling control. Thus, even under the most restrictive standard it is a fair discount that should be recognized in court.

\section{Market Prices and Imbedded Discounts}

It is possible that the award of a control premium in appraisal is intended as a remedy for a market price that reflects an imbedded or inherent minority discount. But the routine addition of a control premium must be based on the implicit assumption that the market price is always low. In a sense, it is probably true that the market price is usually low in that it is usually necessary to offer a premium even over a fair market price in order to gain control of a target company. Thus, to say that market price reflects an imbedded discount may just be a roundabout way to say that the appraisal price should routinely include a control premium. In other words, it assumes the conclusion.

There is another sense, however, in which market price may be said to reflect an imbedded discount. As I have argued elsewhere, there is reason to believe that stocks like other things of value have downward sloping demand curves. ${ }^{98}$ In other words, to sell a block of stock will, other things equal, require that it be offered at a slightly lower price than the prevailing market price, because the potential investor would already have bought at the current price if he or she thought the stock was attractive at that price. By the same token, a potential buyer of stock must offer a little more than the current market price in order to induce an existing shareholder to

\footnotetext{
96 There could also be situations in which the company has inadvertently become exposed to the threat of takeover, such as where shares have been dispersed to subsequent generations of shareholders.

${ }^{97}$ There is, however, no requirement that a once public company continue to comply with SEC reporting requirements once it has terminated registration. See Exchange Act Rule 12g-4. Thus, it may be difficult for former public shareholders to monitor subsequent transactions.

${ }^{98}$ Richard A. Booth, The Efficient Market, Portfolio Theory and the Downward Sloping Demand Hypothesis, 68 N.Y.U. L. Rev. 1187 (1993).
} 
sell. Thus, market price may be said to reflect the opinions of the least optimistic current shareholders (sellers) and the most optimistic potential shareholders (buyers). But as among current shareholders, the average of opinions (reservation prices) will necessarily be higher than the current market price. How much higher is presumably a function of the number of shareholders over which the average is taken. That is, if one wanted to buy 20 percent of the shares one would not likely need to pay as much of a premium as if one wanted to buy 50 percent of the shares.

Some commentators have objected to the downward sloping demand hypothesis on the grounds that all stocks are pretty good substitutes for each other. ${ }^{99}$ And indeed they are in the hands of a diversified investor. But it is unclear that even a diversified investor will fail to consider the value of a single stock as a standalone investment in the context of a merger or takeover in which the buyer by definition must value the target shares at some price in excess of the current market price. In other words, even if the current shareholder might rationally be willing to accept the current market price in the context of an ordinary trade, he or she might also quite rationally insist on some premium over the market price in the context of a transaction in which the buyer seeks a large number of shares. The logic of price-taking by a diversified investor does not necessarily extend beyond ordinary trading transactions.

Although it may be that the notion of imbedded discounts reflects the intuition that downward sloping demand matters, the courts have not indicated that the percentage of shares held by the public or the percentage of shares being sought in a transaction trigger appraisal rights is a factor to be considered. Thus, it is difficult to say at this juncture that downward sloping demand is what the courts are talking about. But given that there are serious objections to including a control premium as an element of fair price in appraisal, perhaps downward sloping demand is what the courts should be talking about.

Finally, although it is always appropriate to ask whether there is some reason to distrust the market price in any given case, it is clear that the market price is not always low. Even the courts have recognized that the market price for a given stock may be inflated because of takeover speculation. ${ }^{100}$ Indeed, in 1999 the Wall Street Journal reported several takeovers at negative premiums. Apparently, in the case of these companies the market had risen to a price in excess of control value. ${ }^{101}$ If the market price of a stock is inflated because of takeover speculation prior to the announcement of a merger, it may be that the market price already reflects some premium for control. The market price may even imbed part of the anticipated gain from the deal, in which case it may be appropriate to impose a discount in an appraisal proceeding to guard against opportunism on the part of dissenters. ${ }^{102}$

\footnotetext{
${ }^{99}$ See, e.g., Frank H. Easterbrook \& Daniel R. Fischel, The Proper Role of a Target's Management in Responding to a Tender Offer, 94 Harv. L. Rev. 1161 (1981).

${ }^{100}$ See, e.g., Moran v. Household International, Inc., 500 A.2d 1346 (Del. 1985).

${ }^{101}$ The same thing may happen as a result of arbitrage during a takeover battle. That, the price of target company stock may increase even beyond the offer price, presumably because the market anticipates a higher offer.

${ }^{102}$ Cf. Moran v. Household International, Inc., 500 A.2d 1346 (Del. 1985) (rights to purchase stock at half of market price in event of takeover attempt justified because market price inflated due to takeover attempt).
} 
It is, of course, also possible that stock price may be depressed because of bad management, looting (or the threat of it), or outright manipulation of the stock price malfeasance, misappropriation, [or] manipulation (as old man Potter put it in It's a Wonderful Life). Where the discount arises because of malfeasance, misappropriation, or manipulation and thus is the fault of management or at least somewhat under management control, it seems clear that management should not be allowed to take advantage of the situation.

On the other hand, if it is simply a thin public market that has depressed the value of shares, it may be argued that market price constitutes fair value. In a sense, the public shareholders may be seen as the cause of the low stock price which may make it unrealistic for the company to use stock as consideration for corporate level transactions or as compensation. Of course, the company could offer more shares to the public. And in that sense, management is in control of the situation. But the new shares would presumably need to be sold at the currently depressed price if indeed they could be sold at all. It may well be that the company never should have gone public in the first place, or that it only became public through a creeping dissemination of its shares, and that to sell more shares will only compound the problem. Finally, in the absence of a rule that says a company must offer some minimum percentage of its shares if it offers any at all, it is difficult to justify a presumption that management should ordinarily fix a thin market by selling more shares.

The distinction between a discount resulting from malfeasance, misappropriation, or manipulation (a true minority discount) and one resulting from a thin market (a marketability discount) is recognized by many authorities, and sometimes makes a difference. There are few (if any) situations in which a it is legitimate to recognize a minority discount in appraisal, but there are some situations in which the courts will impose a marketability discount in making an appraisal award.

In addition, there are any number of other reasons beyond management control why the price of a stock may be temporarily depressed. (A stock that is permanently depressed is presumably just worth less.) And a controlling shareholder may be tempted to take advantage of the situation and use the happenstance of unusual market conditions (such as a market crash) as an opportunity for freezing out the minority. Although at least one court has suggested that it may be coercive to undertake a freezeout at such a time, ${ }^{103}$ it is difficult to justify adding a control premium to an appraisal award because of marketwide conditions as opposed to company-specific factors. On the other hand, if the discount appears to affect one industry but not the market as a whole, an adjustment may be appropriate, although (as will be seen) the adjustment may be more or less automatic if the appraisal court uses the Capital Asset Pricing Model (discussed below) to calculate the appraisal price.

In the end, if the addition of a control premium in appraisal is intended as a remedy for a true imbedded discount - one that arises because of malfeasance, misappropriation, or manipulation rather than the fact that the company is takeover proof - the courts should be

\footnotetext{
${ }^{103}$ Eisenberg v. Chicago Milwaukee Corporation, 537 A.2d 1051 (Del. 1987).
} 
explicit about it and should make a positive determination that the discount exists or at least that there are specific reasons to worry about the threat of looting in the case at hand. Looting is, of course, always a theoretical possibility. But ordinarily managers and controlling shareholders are well motivated to keep stock price high. ${ }^{104}$ Thus, in the absence of specific proof that stock price is depressed below what it would be in the market but for the threat of looting, the court should not adjust the appraisal price because of an imbedded discount. And when such an adjustment is found to appropriate, the court should refrain from calling the adjustment a control premium. Rather, the court should call it what it is, an adjustment for imbedded discount.

On the other hand, if the addition of a control premium is intended to adjust for downward sloping demand, then the court should be explicit about that as well. But the adjustment in such a case should be tied to the percentage of shares in minority hands. If the minority owns 20 percent of the stock, then the adjustment should perhaps be 40 percent of the control premium (on the theory that if the minority owned just over 50 percent of the stock it could command a full premium). Again, the addition of a control premium should be consistent in amount with the theory on which it is based.

Finally, if the addition of a control premium is really now the rule for all cases and minority shareholders are entitled to a control premium even in cases in which a majority shareholder has a lock on control, the court should say so. It could be argued that with state takeover statutes and poison pills, all companies are now essentially takeover proof and therefore that a control premium should routinely be added to all transactions if it is added to any. ${ }^{105}$ Presumably, controlling shareholders would respond (whenever possible) by selling control and leaving minority shareholders in place so as to avoid triggering the appraisal remedy (or by using other techniques such as a sale of assets under Delaware $\$ 271$ that do not carry appraisal rights). ${ }^{106}$ Of course, there may be situations in which the buyer will refuse to deal on such terms.

\footnotetext{
${ }^{104}$ Ronald Gilson has argued that managers of growth companies are well motivated to keep share prices high even if they own an outright controlling interest, because they recognize that they may need to go back to the market for capital. There may be other characteristics that suggests a strong incentive to maintain share price. For example, heavy reliance on stock options for management compensation or frequent use of stock as acquisition currency may tend to vouch for the reliability of the company's stock price. See Ronald J. Gilson, Evaluating Dual Class Common Stock: The Relevance of Substitutes, 73 Va. L. Rev. 807 (1987). On the other hand, controlling shareholders of non growth companies may have a positive incentive to minimize share price in order to facilitate a going private transaction.

${ }^{105}$ To be sure, hostile takeovers arise even where a poison pill is in place. Indeed, there were just as many hostile takeovers in the 1990s, after most companies had adopted pills, as there were in the 1980s before the advent of pills. See generally John C. Coates IV, Measuring the Domain of Mediating Hierarchy: How Contestable Are U.S. Public Corporations? 24 J. Corp. L. 837 (1999); John C. Coates IV, The Contestability of Corporate Control: A Critique of the Scientific Evidence on Takeover Defenses, Harvard Law School Discussion Paper No. 265 (1999). But it may well be that takeovers continue to arise because a target board is legally obligated to redeem a pill in the absence of a threat to stockholder sovereignty. See Quickturn Design Systems, Inc. v. Shapiro, 721 A.2d 1281 (Del. 1998).

${ }^{106}$ Indeed, the court in McMullin v. Beran suggests (at *24) that the defendant subjected itself to the duty to maximize shareholder value because it insisted that the acquirer buy all the shares for cash, suggesting that if the seller had simply sold control it would not have been subject to a duty to maximize. Clearly, that is correct as a matter of law (even in Delaware), but it does rather suggest for future deals that a sale of control that excludes the minority from any participation is the safer alternative. On the other hand, the buyer may insist on buying all of the shares.
} 
And indeed one might argue that if the minority shareholders need to be cashed out (or otherwise dispensed) to get the deal done, then they should get a share of the premium. If the rule is now that a control premium should always be awarded, and this is the rationale, then the courts should say so.

\section{The Capital Asset Pricing Model (CAPM)}

The fact that the market price of an individual stock may be unreliable does not mean that the market as a whole is unreliable as a measure of the value of equities generally. Indeed, even though the market as a whole may move substantially in the space of a day, one would not usually say that stocks on the whole are really worth more or less than the market indicates. Although, one might predict that the market will go up or down in the future and not be dubbed a lunatic, such statements are not taken - even in ordinary conversation - as equivalent to expressing the opinion that the market is wrong. We seem to trust the market as a whole even though we often do not trust the market as to the price of individual stocks. ${ }^{107}$ In other words, assuming that the market as a whole is efficient is very different from assuming that the price of any individual stock is accurate.

Fortunately, the Capital Asset Pricing Model (CAPM) provides a way to estimate the value of a company using the market as a whole to control for aberrations in the market price of individual stocks. It should be noted at the outset that CAPM is not perfect. For example, it seems routinely to overvalue small companies thus requiring a significant adjustment. ${ }^{108}$ Nevertheless, CAPM is widely accepted in the financial community and indeed in the courts where it has been cited no fewer than 85 times (fifteen of which cites arise in Delaware cases). ${ }^{109}$

In order to explain how CAPM works and how it deals with imbedded discounts and other valuation problems, it is necessary first to outline how one calculates the going concern value of a business.

\section{A. $\quad$ Going Concern Value}

The basic formula for determining going concern value is:

$$
\text { Going Concern Value }=\text { Expected Return } / \text { Capitalization Rate }{ }^{110}
$$

\footnotetext{
${ }^{107}$ See MELVIN A. EISENBERG, THE STRUCTURE OF CORPORATION LAW 77-82 (1976).

${ }^{108}$ For a very readable discussion of CAPM and its shortcomings, see BURTON G. MALKIEL, A RANDOM WALK DOWN WALL STREET 227-76 (1996).

${ }^{109}$ See study as of August 1, 2000 on file with the author.

${ }^{110}$ See HAMILTON \& BOOTH, BUSINESS BASICS FOR LAW STUDENTS $§ 8.7$. This formula is simply a rearrangement of the formula for calculating simple interest on a bank account, that is, principal $\times$ interest rate $=$ return.
} 
The capitalization rate is the required rate of return given the riskiness of the company (expressed as a decimal percentage). Dividing by the capitalization rate is equivalent to multiplying by the reciprocal of the capitalization rate. Thus, if the capitalization rate is 20 percent (.20), one might just as well think of the operation as multiplying the expected return by five (1/.20). Indeed, it is common to think of going concern value as a multiple of earnings, and indeed many seem to prefer the idea of applying a multiplier to earnings rather than dividing by the capitalization rate (perhaps out of fear of fractions or division or both). In any event, the object is the same:

\section{Going Concern Value / Expected Return $=1 /$ Capitalization Rate $=$ Multiplier}

When the multiplier is expressed in terms of price per share compared to earnings per share (rather than in the aggregate for the company) the relationship is the familiar price / earnings ratio or $\mathrm{P} / \mathrm{E}$ ratio.

Regrettably, although the formula is easy to express and understand, it is quite difficult to apply with any accuracy. There are two basic problems. First, it is difficult to predict the return a company will generate. Second, it is even more difficult to determine how risky that return is and thus what the required rate of return should be. As should be apparent from the formula, the higher the required rate of return, the bigger the denominator, and the smaller the value of the company (and vice versa).

\section{B. $\quad$ Estimating Risk and Required Return Under CAPM}

CAPM greatly simplifies the process of determining the appropriate capitalization rate. CAPM may be used to determine both the risk inherent in the subject stock and the required rate of return at that level of risk. Under CAPM, the capitalization rate is solely a function of risk. And risk is simply a measure of the tendency of a given stock to move with the market, a function dubbed the beta coefficient. Thus, if the marketwide rate of return is 10 percent in excess of the riskless rate of return, and if the subject stock tends to move half again as much as the market - a beta of 1.5 - then the capitalization rate for the stock in question should be 15 percent plus the riskless rate of return.

Although it has been suggested in the heat of litigation that using CAPM to determine the value of a company is just a roundabout way of relying on market price, using CAPM differs fundamentally from using the price/earnings ratio $(\mathrm{P} / \mathrm{E})$. First, $\mathrm{P} / \mathrm{E}$ uses the price of the stock in question and thus freights in any aberrations in the pricing of that stock. Second, as it is usually calculated, P/E uses earnings from the last year (trailing earnings), rather than any projection of future cash earnings. Although the past is often a good predictor of the future, investors clearly care about the future, especially when it is likely to differ from the past. Finally, earnings as calculated under GAAP are not a very good indication of cash flow - the ability of the company to distribute returns to its investors. Although one can massage earnings to adjust for the latter two shortcomings, using market price as the numerator of the ratio is the kiss of death for using the $\mathrm{P} / \mathrm{E}$ ratio to find the capitalization rate. To put it bluntly, using $\mathrm{P} / \mathrm{E}$ to find the capitalization rate $i$ s a roundabout way of relying on market price. If one of the fundamental goals of appraisal is to double check the market price, then using $\mathrm{P} / \mathrm{E}$ is rather like buying an extra newspaper to 
verify the facts of a story. ${ }^{111}$ Using CAPM largely controls for discrepancies in market pricing by focusing not on absolute market price but rather on the volatility of market price (the tendency of the price to jump around) which, after all, is the very definition of risk. Whether a stock is overvalued or undervalued as a matter of its absolute price, the tendency of the stock to move up or down by more or less than the market should be unaffected by the absolute level of the price. ${ }^{112}$ Although CAPM uses market prices as raw data, it does not presume the accuracy of those prices in any absolute sense. Thus, it is not the case that CAPM is just a backdoor way of relying on market price as has been suggested by some litigants. ${ }^{113}$ Finally, it is worth noting that no case or secondary authority appears to have discussed this rationale for using CAPM up to now. Even if CAPM is somewhat flawed as a theoretical matter, it still controls - in a rational way - for idiosyncratic differences in the market prices of various stocks and even various industries.

Yet another advantage of using CAPM is that it gives shareholders what they deserve in the sense that it gives them what they should rationally expect from an investment in the subject stock. Ultimately CAPM values an individual stock on the basis of its contribution to a marketwide portfolio. Thus, using CAPM effectively assumes that a dissenting investor is well diversified as any rational investor should be. In other words, CAPM does not protect stock pickers. But it is unclear that stock pickers deserve protection. An investor cannot rationally expect to beat the market as whole as adjusted for risk. On the other hand, an investor can rationally expect to match the market. And CAPM does that by ensuring that stockholders get at least a market rate of return. ${ }^{114}$ No one would likely say that the object of appraisal is to protect investor hopes and dreams. Yet that is the tenor of many appraisal proceedings in which disgruntled investors seek to show that if they had been allowed to hang on to their stock they would have made a killing. The routine addition of a control premium reinforces that view of the appraisal remedy. Thus, it is important to be clear that a premium is appropriate only in those

\footnotetext{
${ }^{111}$ To be sure, it may make some sense to look at the average P/E ratio for an industry or indeed for the market as a whole and to compare the P/E ratio for the company in question. But even this method has serious shortcomings. First, GAAP affects different industries in different ways. For example, high technology industries are typically required to expense much of their research and development costs, thus depressing earnings. Accordingly, the P/E ratio appears to be higher than it would otherwise be, and other companies appear to be undervalued. Indeed, some old economy companies have considered going private because they perceive that they are out of favor with the market and may be able to borrow enough money at lower interest rates than the implicit rate of return on their stock. Second, even in the absence of accounting discrepancies, the market tends to cycle from industry to industry so that at any given time some industries will be in favor and some will be out of favor.

112 This is not to say that the beta of a given stock is constant or even stable over time. See, e.g., Cede \& Co. v. Technicolor, Inc., 1990 Del. Ch. LEXIS 259 (beta of subject company increased from 1.27 to 1.7 over three month period possibly because of announcement of tender offer and changes in business plan even though tender offer was at more than 100 percent premium over market price).

${ }^{113}$ See, e.g., Cede \& Co. v. Technicolor, Inc., 1990 Del. Ch. LEXIS 259.

${ }^{114}$ CAPM price is already higher than company specific price would be in that it assumes the holder is a diversified investor.
} 
situations in which an investor should expect a premium, namely, in sale of control transactions. ${ }^{115}$

\section{C. $\quad$ CAPM, Control Premiums, and Imbedded Discounts}

The price of a given stock as calculated under CAPM does not reflect a premium for control in the conventional company-specific sense. Rather, the CAPM price is based on the required return for comparable companies in ordinary circumstances. And that, in essence, is the price that most appraisal statutes are aimed at determining, namely, the fair value without any addition or subtraction for the effect of the transaction in question. ${ }^{116}$ Thus, in an appraisal proceeding in connection with a change of control transaction it may be necessary to consider premiums in comparable transactions. Then again, it may be that some companies become targets because their stock is undervalued compared to its ideal CAPM price. Thus, a court must be careful to distinguish (if possible) between a true premium for control and one that is arises simply because of an imbedded discount.

Although the price of a stock as estimated under CAPM will not reflect any companyspecific premium for control, CAPM may reflect a generic premium for control in at least two ways. First, the market rate of return over any given period is an average of the return on all stocks in the market, including returns from takeover premiums on target stocks during the period. Thus, control premiums are part of the average (at least to the extent that sale of control transactions during the period involve publicly traded shares). Second, CAPM may reflect industry-specific or even company-specific premiums in some situations. If takeover speculation has caused the market price of a given company (or market prices in a given industry) to resist market downturns, then the calculation of beta may be affected (assuming that upside volatility has not increased similarly).

As for imbedded discounts, using CAPM automatically adjusts for any company-specific discount because the price is ultimately based on a marketwide average rate of return. Thus, it is

\footnotetext{
${ }^{115}$ The appraisal remedy has been criticized as an unnecessary expense in a world of diversified investors. A diversified investor will reason that even if the price paid is low in some cases, it will be high in other cases. You win some, and you lose some, but only the average matters. Thus, if diversified investors could vote on whether to retain the appraisal remedy, they would likely vote against retention, because they would view appraisal is an unnecessary expense for the corporation that reduces overall return. On the other hand, in the absence of an appraisal remedy, controlling shareholders (as a class) might be tempted to cherrypick the deals that result in the appropriation of minority wealth. Diversification cannot protect against a pattern of transactions that tends to skew the average. The latest revisions to the MBCA speak to these problems by eliminating the appraisal remedy for publicly traded companies except when a 20 percent or greater shareholder or other controlling person will continue as a controlling person in the successor corporation. Needless to say, appraisal is a more important protection in the context of a thinly traded or private company, because shareholders in such companies are less able to diversify.

${ }^{116}$ See PCG §7.22(b); MBCA §13.01(4); DGCL 262(h). The PCG is somewhat confused on the standard of fair value in connection with interested mergers. Although PCG \$7.22(a) provides that value should be determined in the context of the transaction - and the commentary thus suggests that where no control premium could be expected none should be awarded $-\S 7.22(\mathrm{c})$ provides that in the context of an interested transaction (such as a parentsubsidiary freezeout merger where the parent already owns an outright controlling interest), the appraisal should include a control premium.
} 
inappropriate to adjust a CAPM price upward because of a supposed imbedded discount. ${ }^{117}$ It may, however, be necessary to adjust the CAPM price downward to reflect a limited market for the shares in cases in which such an adjustment is appropriate (as where it affects all the shares). Again, CAPM is based on marketwide averages for all publicly traded shares and to the extent that shares are more valuable because they are readily tradable, CAPM may thus indicate a higher than fair price for a stock with little or no market.

\section{Discounts and the Function of Appraisal}

The idea that the standard of value in an appraisal proceeding should reflect the actual transaction under review is necessitated by the nature of the appraisal remedy. The point of the appraisal remedy is to determine whether the price paid in a merger or other fundamental transaction is fair. ${ }^{118}$ It is not intended as a way to review the wisdom or terms of a deal even though it may be appropriate in some circumstances to consider how the deal was negotiated in determining fair price. ${ }^{119}$ For example, if the negotiations were tainted by a conflict of interest, it may be appropriate to adjust the appraisal price. In other words, the point of appraisal is to double check the price of the deal - not to second guess the deal itself. The appraisal remedy is not intended to be a dismissal-proof substitute for litigation in which the plaintiff need not even make out a case.

As a matter of policy, it is important that appraisal not be used as a way for holdout shareholders to second-guess the will of the rest of the minority shareholders. If dissenters are permitted to challenge the terms of a deal in an appraisal proceeding, it would undermine the process by which mergers and other fundamental transactions are supposed to be ratified. Shareholders might often be tempted to vote against even good deals as a way of preserving their appraisal rights and seeking a better deal in court. It follows that if a deal has been properly negotiated and approved, the appraisal court should presume that the price is fair and award at most that price. ${ }^{120}$ It may even be appropriate to penalize dissenters with a discount, perhaps by

\footnotetext{
${ }^{117}$ In some cases, appraisers use industry betas rather than the subject company beta to adjust for the possibility of noise in any single company beta. Although this technique is not inherently objectionable, it is subject to some manipulation in defining peer institutions. The dangers are akin to those that inhere in defining a market for antitrust purposes.

${ }^{118}$ See generally Daniel R. Fischel, The Appraisal Remedy in Corporate Law, 1983 Am. B. Found. Res. J. 875; Hideki Kanda \& Saul Levmore, The Appraisal Remedy and the Goals of Corporate Law, 32 UCLA L. Rev. 429 (1985); Randall S. Thomas, Revising The Delaware Appraisal Statute, 3 Del. L. Rev. 1 (2000); Robert B. Thompson, Exit, Liquidity, and Majority Rule: Appraisal Role in Corporate Law, 84 Geo. L.J. 1 (1994); Barry M. Wertheimer, The Shareholder's Appraisal Remedy and How Courts Determine Fair Value, 47 Duke L.J. 613 (1998).

${ }^{119}$ See Weinberger v. UOP, Inc., 457 A.2d 701 (Del 1983).

${ }^{120}$ A fortiori, to award more than the negotiated price would constitute a windfall to the dissenters and would encourage dissent in future transactions. Indeed, it would encourage minority shareholders always to vote against such transactions rather than to vote on the merits, because a shareholder who votes in favor of a transaction may not thereafter assert appraisal rights. Moreover, and perhaps more important, to award a higher price to the dissenters would render meaningless the efforts of the majority to assure fair dealing.
} 
relegating them to market price. ${ }^{121}$ But it will probably suffice in most cases to assess costs and attorney fees against them as the MBCA permits. ${ }^{122}$ In any event, if a merger is subjected to a majority of the minority vote after full disclosure, and a majority of the minority vote to accept the offer, the merger price should be presumed fair in an appraisal proceeding.

Most authorities agree that it may be appropriate to apply a discount if it appears that dissenting shareholders have held out in effect to elicit a bribe or have chosen to speculate on the future course of action of the corporation. ${ }^{123}$ Similarly, pursuit of appraisal in an effort to extract the equivalent of a sale of control price -- even though the dissenters do not have the voting power to force such a sale -- may be grounds for imposing a discount. Indeed, a discount or penalty may be appropriate where a shareholder has undertaken appraisal frivolously when a fair offer was on the table. ${ }^{124}$ A discount of sorts (in the form of a delayed payment) may also be warranted where an investor has bought into appraisal rights. ${ }^{125}$

\section{Conclusion}

One of the most fundamental questions of corporation law is whether a controlling shareholder is obligated to maximize shareholder value. ${ }^{126}$ Here the question is whether there is a duty to maximize to the extent that a controlling shareholder is required to pay third-party auction value to cash out the minority where it is clear that the company is not up for sale. ${ }^{127}$

If there is any legitimate reason for a controlling shareholder to get rid of minority public shareholders, then it is difficult to see why a controlling shareholder should be forced, in effect,

\footnotetext{
${ }^{121}$ See PCG $\$ 7.22$ Comment (e) ("court could find that the shareholder was opportunistically exploiting a change in the charter that was relatively minor, and to which the shareholder had no real objection"). See, e.g., Lawson Mardon Wheaton, Inc. v. Smith, 315 N.J.Super. 32, 716 A.2d 550 (1998) (dissenters exploited restructuring undertaken for tax advantages; marketability discount upheld), rev'd, 734 A.2d 738 (N.J. 1999) (no extraordinary circumstances present). See generally Richard A. Booth, The New Law of Freeze-Out Mergers, 49 Mo. L. Rev. 517 (1984).
}

${ }^{122}$ See MBCA $§ 13.31$. But see MBCA $§ 14.34$ (party who seeks involuntary dissolution must risk buyout at discounted price).

${ }^{123}$ See PCG $\$ 7.22$ at 325. Cf. Matteson v. Ziebarth, 40 Wash.2d 286, 242 P.2d 1025 (1952) (upholding freezeout merger where minority shareholder sought to extort portion of salary to be paid to controlling shareholder by successor corporation in exchange for giving up shares).

${ }^{124}$ See MBCA $\$ 13.31$ (court costs and attorney fees may be assessed against plaintiff if he or she acted arbitrarily, vexatiously, or other than in good faith). See also Weinberger v. UOP, Inc., 457 A.2d 701 (Del 1983).

125 See MBCA $§ 13.25$ and Official Comment (to discourage speculation on appraisal results, immediate payment of corporation's estimate of fair value not required as to after-acquired shares).

${ }^{126}$ See Richard A. Booth, Stockholders, Stakeholders, and Bagholders (Or How Investor Diversification Affects Fiduciary Duty), 53 Bus. Law. 429 (1998) (arguing that there is no general duty to maximize other than as imposed by market forces).

${ }^{127}$ Similar considerations apply where the sale is at the discretion of the controlling shareholder. See McMullin v. Beran, 2000 Del. LEXIS 481 at $* 25$. 
to buy control all over again by paying a control premium to any holdouts - especially if the minority willingly bought into its position. Clearly there are legitimate reasons to get rid of public shareholders, ranging from saving the cost of registration and reporting, to avoiding shareholder litigation, to gaining advantageous tax status, to ridding the company of a pessimistic market price that may have the effect of unduly depressing the net worth of the controlling shareholder. It is also clear, however, that it is not necessary (at least in Delaware) to prove any business purpose. ${ }^{128}$ And other things equal, it is difficult to think that going public should be a one-way street. Still, as with going private deals in general, the question of control premiums in appraisal raises the question whether the shareholders really own the company and whether all shareholders are really equal.

Appraisal statutes invariably specify that an appraisal award should be based on the value of the firm before the proposed transaction. In other words, the dissenters should be compensated for what they gave up and are not entitled to a share of the benefits of the transaction anticipated by the surviving shareholders. In other words, appraisal is a floor not a ceiling. It is a safety net. And it is wholly consistent with the idea that the majority is entitled to run the company as it sees fit as long as any gain it enjoys is not at the expense of the minority. ${ }^{129}$

Finally, it is unclear that public shareholders would see much if any benefit from an across the board rule that awarded them a control premium in appraisal. As a practical matter, a controlling shareholder could either do nothing or could sell control, leaving the minority shareholders in place and denying them any premium at all. So what is the point?

\footnotetext{
${ }^{128}$ See Weinberger v. UOP, Inc., 457 A.2d 701 (Del 1983).

${ }^{129}$ The distinction here, which is well established as a matter of Delaware law (see Sinclair Oil Corp. v. Levien, 280 A.2d 717 (Del. 1971)), is the same as the distinction in economics between Pareto efficiency (a transaction that makes everyone better off) and Kaldor-Hicks efficiency (a transaction that makes some better off but makes no one worse off). See RICHARD A. POSNER, ECONOMIC ANALYSIS OF LAW 12-14 (3d ed., 1986).
} 